\title{
リグニンの利用
}

\section{畠山 兵衛}

Hyoe Hatakeyama, 工業技術䟚 製品科学研究所

\section{1. は じめに}

近年, 自然科学技術の「進歩への確信」が日本とい う限定された地域内だけでなく, 全地球的規模に物げ るエネルギー源の枯渴，環境污染破壤といら敩しい現 実直面して摇らぎはじめている。資源エネルギー問 題が影在化する直接の引金になったのは, 1973 年の

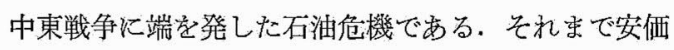
飞大量生産できるるのの代名詞のよう《考光られてい た石油製品が，決して安くないばかりか，石油保有国 の動向いかれではその供給すら安定したものでないこ とが明らかとなった。しかし，このような問題は人頩 が化石資源で势る石油, 石炭に依存しはじめた時から 内在していたとい觉る。

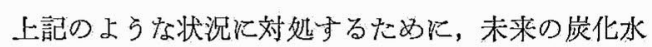
素源として，最近急速汇植物資源が注目を集めるよう

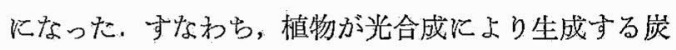
化水素, 炭水化物海るいはリグニンなどを有效に各種 工業原料として利用しようとするもので岁る。例克 ば,ノーベル賞受賞者の M. Calvin 教授の提唱する 石油植物, 最近上く耳汇するりニューアブル資源, バ イオマスなどといら言葉も改めて植物資源を見直し， 有效に利用できないるのかといら一連の研究克るいは 開発への努力考含むとい党よう.

いわ沺る植物資源の場合, 食糧之して昔から利用さ れているデンプンを除いては，木本性の高等植物から 得られるセルロース，へミセルロース频よびリグニン が量的にみて最る注目に值する。 その理由はこれらが 炭化水素原料之して, 工業化しうる規模に执いて大量 に得られるリニューアブル資源で少るためである。 ルロース, ヘミセルロース特よびリグニンは, 樹種に よって変動があるが，木材中にそれぞれ 30〜 50\%, 10 〜20\% 特よび 20 30\%存在する. そのうち利用され ているのは現在のところせルロースだけであり、へミ

Utilization of Lignin.
セルロースやリダニンの有効利用は今後の問題として 残されている。

\section{2. リグニンの分布と構造}

植物組織中以新跱るリグニンの発生は, 植物の進化 の過程と密接に結びついていて、リグニンは維管束を 持つシダ類以上の高等植物にのみ特異的に存在する.

一般に細胞分裂によってできたばかりの細胞は壁もう すく、ペクチン質などの酸性多糖類に富んでいるが， しだい《セルロース捛よび中性のへミセルロースが形 成され，細胞がそれぞれ特有の木部細胞（木繊維, 仗 導管，導管）などに分化し，二次壁が形成される頃に なると一次壁からリグニンの形成が始をる．この現象 は一般に木化 (lignification) といわ机る。

リグニンの種類は植物の進化とともに変化して和 り, シダ類や針葉樹のリグニンは主としてコニフェり ルアルコール(1)の脱水素重合体であって, グアヤシ ル基 (2) を主要構成分とするグアヤシルリグニン (guaiacyl lignin) である. 一方, 広葉樹を中心とす る被子稙物のリグニンはコニフェりルアルコールとシ ナピルアルコール(3)の共重合体からなるグアヤシル． シリンギルリグニン (guaiacyl-syringyl lignin)であ る. 被子植物中のイネ科植物のリグニンはコニフェリ ルアルコール, シナピルアルコール和よび $p$-クマリ ルアルコール（4）の共重合体グアヤシルーシリンギル. p-ヒドロキシフェニルリグニン (guaiacyl-syringyl-

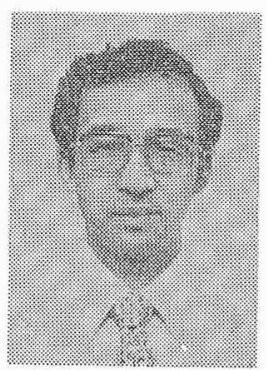

皇山兵衛 工業技術院 製品科 学研究所 (305 荻城県筑波郡谷田 竞町東 1) 植物材料課長. 農博 昭和43年東京大学農学部大学院博 士課程修了. 44 年製科研入兹. 45 $\sim 47$ 年スウェーデン王立工科大学 留学, 51 年上り現職. 專門は木材 化学. 現在の研究梳糖類の固体物 性,リグニン関連型化合物の合成 と物性. 〈趣味〉スキ一, テニス 
p-hydroxyphenyl lignin) 飞p-クマール酸 (5) がエ ステル結合していることが知られている：すなるかりり グニンは植物のグループによって3大別される．この ようなりグニンの構造上の差異は植物グループ間でり グニン生合成経路が異なっているためと考兄られてい る.

\section{3. リグニンの用途}

これまでのところリグニンは主としてパルプ製造時 炕抢ける副生物として得られるだめ, 排液処理の立場 からは，濃縮して然料として利用するのが最も得策で あるとされていた，乙かし，最近は各種の用途が開発 され，数年前とは事情がかなり違ってきている。

Falkehag' ${ }^{1)}$ とれば、リグニンの用途は次の上うに 分類される. (a) エネルギー源，(b) 紙，ボード類， (c) 分解括よび化学反応生成物（例 : バニリン,ドー ペ, ジメチルスルフィド, ジメチルスルホキシド，フ ェノール, カテコールおよび 各種ベンゼン誘尊体),

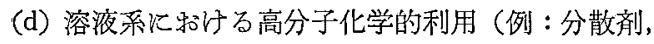
乳化安定剂, 錯塩形成剂, 沈殿剂, 凝集剂など)，(e) 高分子材料分野における利用，(f）マトリックスある いはゲルとしての利用，(g) 炭化拈よび熱分解（例： 活性炭, 炭素批よびグラファイト)，(h) 土壤安定剤 および肥料などである.

ここでは紙面が限られているので，リグニンの代表
第 1 表 わが国におけるリグニン製品用途別需要量 $(1977)^{2)}$

\begin{tabular}{|c|c|c|}
\hline 用 & 主効果 & $\begin{array}{l}\text { 需 要 } \\
\text { (固形分 } \mathbf{t} / \text { 年) }\end{array}$ \\
\hline コンクリート減水剤 & 分散性 & 49,000 \\
\hline 粉鉱造粒剂 & 粘結性 & 26,000 \\
\hline 肥料造粒剂，土壤改良剂 & $\begin{array}{l}\text { 粘結・ } \\
\quad \neq \text { キート性 }\end{array}$ & 7,000 \\
\hline 墨業用粘結荗, 分散剤 & 粘結·分散性 & 4,000 \\
\hline 農薬分散，造粒剤 & 粘結 · 分致性 & 3,000 \\
\hline $\begin{array}{l}\text { 豆練炭, 活性炭, } \\
\text { カーボンブラック造粒剂 }\end{array}$ & 粘結性 & 2,000 \\
\hline 染料，顔料，インキ分散剤 & 分散性 & 2,000 \\
\hline 泥水調整剂 & 分散珄 & 2,000 \\
\hline セッコウボード用添加荗 & 分散性 & 1,000 \\
\hline 鋳物砂用添加剂 & 粘結性 & 1,000 \\
\hline その他 & 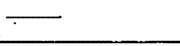 & 8,000 \\
\hline 計 & & 105,000 \\
\hline
\end{tabular}

的利用法および有機化学の立場から考察してのリグニ ンの応用や実用の可能性について，いくつかの例につ いて述ぺる。

\section{3-1. 未加工あるいは半加工のリグニン製品}

パルプ排液から得られるリグニンになるべく手を加 えないで, リグニンの特質をそのまを生かした製品で あって, サルファイト蒸解排液から得られるリグノス ルホン酸塩とクラフト蒸解排液から得られるクラフト リグニンとではとの用途が若干異なる.

サルファイト蒸解排液から得られるリグニン製品と
$\mathrm{CH}_{2} \mathrm{OH}-\mathrm{CH}=\mathrm{CH}-\mathrm{O}-\mathrm{OH}$<smiles>COc1ccc(C)cc1O</smiles><smiles>COc1ccc(O)c(O)c1</smiles><smiles>COC=Cc1cc(OC)c(O)c(OC)c1</smiles><smiles>COC=Cc1ccc(O)cc1</smiles><smiles>O=C(O)C=Cc1ccc(O)cc1</smiles><smiles>COc1cc(OC)cc(OC)c1</smiles>
$\mathrm{OCH}_{3}$<smiles>COc1cc(OC(C)=O)ccc1O</smiles><smiles>COc1ccc(OCCOCc2cc(OC)c(OC)cc2OC)cc1</smiles><smiles>COc1ccc(CCCC(=O)O)cc1OC</smiles>

15<smiles>COc1cc(OC)c(O)c(OC)c1</smiles><smiles>COc1cc(CC2NCCc3cc(O)c(O)cc32)cc(OC)c1OC</smiles>
$16 \mathrm{OCH}_{3}$<smiles>CCCCCCCC(=O)Oc1cc(OC)c(OC)c(OC)c1</smiles>

17<smiles>COc1cc(Cc2ncc(N)cn2)cc(OC)c1OC</smiles><smiles>COc1cc(OC=NCc2ccc(OCCN(C)C)cc2)cc(OC)c1OC</smiles><smiles>CCCCOc1c(OC)cc(C(=O)O)cc1OC</smiles><smiles>C[AlH2]=CCOc1ccc(OC(=O)OCc2ccccc2)cc1</smiles><smiles>CCCCCOc1ccc(OC(=O)O)cc1OC</smiles>
22 $\mathrm{R}_{1}$<smiles>CCCC(=O)Oc1ccc(OC)cc1</smiles><smiles>[R]c1cc(/C=C/C(=O)O)cc([R2])c1O</smiles>

24 25

$\left[-\mathrm{CH}_{2}-\mathrm{CH}(-\mathrm{O}-\mathrm{OH})-\right]_{n}$ 27

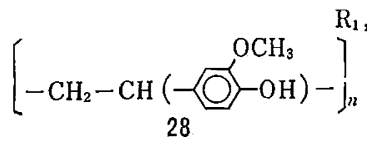
28

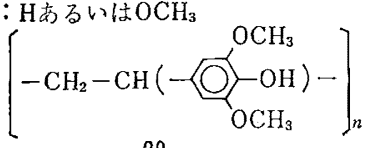




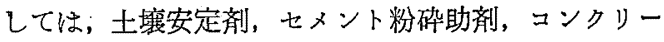
卜減水剂, 泥水調整剂, 肥料用バインダー，土質改良 剂, 農薬バインダーなどがめり，その代表例之需要量 を第1表に示す。

クラフトリグニンの場合には, フェノール系樹脂や ゴムなどへの添加剤として利用されている.しかし，ク ラフトリグニンを熱硬化性樹脂にフェノールの代替と して添加する時には, 粘度あるいは硬化速度への影響 のため, 量的制限がある. 詳細についてはすでにいく つかの報告があるので，それらを参照されたい1) 5).

またクラフトリグニンをゴムの增強剤として使用 する際には，尿素一ホルムアルデヒド樹脂あるいはフ ェノールホルムアルデヒド樹脂と共重合させた後，ア ルカリ溶液からゴムと共沈させて使用する例が多く， 特許も数多〈出されている(6) B).

\section{3-2. リグニンから得られるファインケミカル}

リグニンをファインケミカルに転換する方法のら ち, 工業化㵊む成功しているのはバニリン(6)の製 造である. 原料としては針葉獙材のサルファイト蒸解 排液から得られるリグノスルホン酸が用いられる。: ニリンはこれをアルカリ性下に酸化することによって 得られ，収率は製造条件によって数\%から十数\%京で 変化する. 現在，世界で年間約 $5,300 \mathrm{t}$ のバニリンが リグニンを原料として製造されているが，供給が需要 に追いつかないといわれる。

バニリン誘導体としては香料として用いられるェチ ルバニリンの他に，医薬用としてメチルドーパ9（血 管拡張剂)，ドーパ10) (パーキンソン氏病薬）打よび 医薬品中間体として，7〜9などのグアヤシル誘導体 や 10〜15 などのベラトルム誘導体が Borregaad 社から出されている。

広葉樹りグノスルホン酸の酸化分解飞よってシリン ガアルデヒド（16）が得られる。この物質は，例壳ば 次のよらな医薬品の医薬中間原料として用いられてい る.すなわち，(a）血管拡張郕（ヘキソベンジン） (17)，(b) 鎮咳タン剂(トリメトキノール)(18), (c) 化学療法剤（トリメトプリム）(19)，(d) 催呡鎮静・ 降圧利尿剂（トリメトベンザミド（20）などである.

また上記のバニリンやシリンガアルデヒドの他にイ ネ科植物のリグニンから得られる 4-ヒドロキシベン ズアルデヒドは一連の液晶性物質の出発原料となる。

これらのうち，4-ヒドロキシベンズアルデヒドから誘 導される 4-nーアルコキシ安息香酸 (21) は液晶性の物 質として有名であり，多くの報告がある ${ }^{11 〉 16) . ~}$

筆者の研究室でアルキル鎖の鎖長を変えて,グアヤ シル系の 4-nーアルコキシ-3・メトキシ安息香酸 (22) およびシリンギル系の 4-n-アルコキシ-3, 5 -ジメトキ

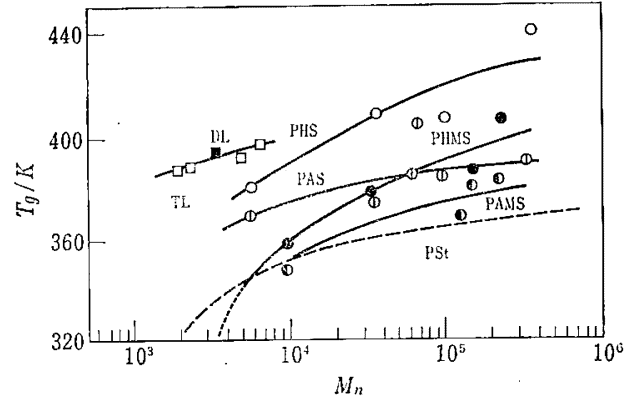

DL：ジオキサンリグニン, TL：チオリグニン, PHS : ポリ(4ーヒドロキシスチレン), PAS : ポ り(4ーアセトキシスチレン), PHMS : ポリ(4-ヒ ドロキシー3ーメトキシスチレン), PAMS : ポリ (4-アセトキシ-3ーメトキシステレン), PSt : ポリ スチレン

\section{第1図 ガラス転移温度 $\left(T_{g}\right)$ に及ぼす化学棈造と 分子量の影響}

シ安息香酸 (23) を合成し，その性質を調べたところ， 芳香核の3-位要るいは3, 5 -位へのメトキシル基の導入 によりその熱的性質が通常の 4-n-アルコキシ安息香 酸とは著しく異なることが見いだされた。すなわち， 等方性液体への転移温度が分子長, 特よび分子幅に上 って，どのように変化するかを測定したところ, 転移 温度に対しては分子幅の影響が大で,リグニンの特徵 の一つである芳香核についたメトキシル基の影響を無 視できないことが明らかとなった苂。これは将来りグ ニンを液晶性物質の原料とする場合のメリット㘯るい はデメリットの原因となると考觉られ與味深い。

\section{3-3. リグニンから得られる合成高分子}

リグニンから得られる 4-ヒドロキシベンズアルデ ヒド, バニリン, シリンガフルデヒドなどのフェノー 儿誘導体を原料として，容易にポリエステル，ポリエ 一テル，ポリビニルなどの合成高分子が得られる。 こ れらのう虫ひ，バニリンを原料とするポリエステル は，下式のよらなスキームで合成され，物理的性質

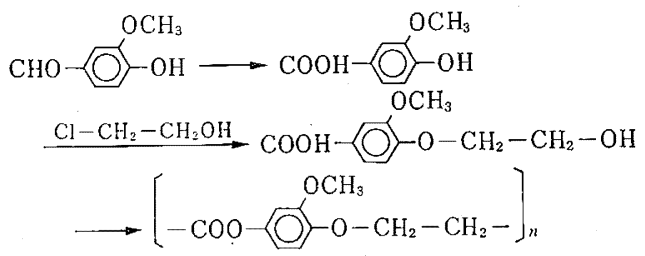

る優れたるのとして知られているけれども, 開発時 期が 1950 年代であったため, 急速に発展した石油化 学製品に比べて, 経済的に引き合わず実用化されなか った。しかし，石油危機以後の慢性的石油不足と価格 の高騰に伴い,このようなリク゚ノケミカルからの繊維 製品も将来重要なものとなろう. 


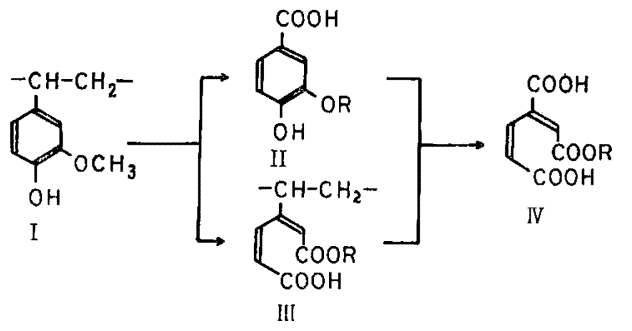

$\longrightarrow \int_{\mathrm{V}}^{\mathrm{COOH}}+\begin{gathered}\mathrm{COOH} \\ \mathrm{COOR} \\ \mathrm{VI}\end{gathered}$

\section{第 2 図 リグニン関連型スチレン誘導体の微生物分解過程}

ポリエーテルとしては poly(oxy-1, 4-phenylenecarbonyl-methylene) (24) や poly(oxy-2-methoxy1,4-phenylenecarbonylmethylene) (25) がすで合 成されている18). そのガラス転移温度 $\left(T_{g}\right)$ も同じ分 子量を有する他のポリマーに比して高く, 熱的によい 性質を示す ${ }^{18)}$. しかし, 高重合度のものを得るのが現 時点では困難であり, 検討を要する.

ポリビニルタイプとしてはスチレン誘導体の形をし
たものがあり，モノマーの合成は実験室的にはシンナ ミック酸誘導体（26）の脱炭酸によって行ならのが比 較的容易である ${ }^{19)}$. ポリ(4-ヒドロキシスチレン) (27), ポリ(4-ヒドロキシー3ーメトキシスチレン) (28), ポリ (4-ヒドロキシ-3,5-ジメトキシスチレン) (29) 拉 びそ机らのアセテートについて物理的性質を調べる と，4-位のフェノール性水酸基と 3 -位のメトキシル 基の影響が大である。例壳ば，第 1 函に示すように同 じ分子量に捇いてポリスチレンよりは一般に高い $T_{g}$ を示す.ここでフェノール性水酸基は, 水素結合の形 成により $T_{g}$ を引き上げる方向に作用し, メトキシル 基は逆に引き下げる方向に作用していることが明らか にされている20),21)。な特，このようなリグニンを原 料として得られるスチレン誘導体は第 2 図に示すよう な過程を経て, 土壇中の微生物により資化されるた $め^{19)}$, 公害対策上の観点からも興味があるう。

\section{4.おおりに}

以上に述べたように,リグニンの利用に関する基礎

(870 頁へ統く)

\section{ネコラム}

\section{リグニン利用の技術的問題点}

1853 年に英国の Watt と Burgess がソーダパルプ製造法, 1866 年米国の Tilghman が亜硫酸パ ルプの製法特許をとって以来, こ れらの薬液で木材を蒸解するパル プ製造法は，工業化されて以後す でに 100 年にわたり、リグニンを 副成し続子てきた。この間, 生産 されたパルプの約半分の重量のリ グニンが廃液として河川を活染 し，一部は熱エネルギーとして活 用されたが大気を活してきた。

この 100 年間, 世界中の学者や 技術者が，リグニンの有效利用法 を研究し，数えきれない核どの特 許や研究が発表されてきた，何度 か高額の䀣賞金がかけられたこと もある、にもかかわらず不幸にし ていまだリグニンを資源化できた 技術はないといっても過言ではな い.ちょうどこの㭙代, 石炭・石 油・水力発電のエネルギーは安 く，地下の資源は無尽蔵と考えら れていた．有機化学工業は石炭か ら始まり石油に変わったとはい 光, 安い資源加ら得られる炭化水 素の上に組み立てられてきた。り
グニンはメトキシフェノール基と いら特徵のあるグループを持ら, 酸素が多く椿造が複雑で一定せず 扱い難い，しかも，現在の主流で ある KP \& SP む，チオール基 かスルホン酸基かいずれかの硫黄 を含もリグニンを副成しているの である、さらに原木・薬液・蒸解 条件・後処理条件により, 廃液中 のリグニンの構造・組成・物性は 大きく変化するという問題点をか 加ている。

原油の值上がりにより, リグニ ソは低カロリーながら排煙脱硫装 置を完備するか. $\mathrm{SO}_{2}$ 総量規制が なければ，然料にするのが得策と いう情なさが日本の現状である.

現在, リグニンはその粘結性を 利用して㖘薬・肥料などの造粒用 や, 豆炭練炭・鋳型などの粘結用 と, 亡た，京の分散性キレート性 を利用してコンクリート減水剂 . 顔料分散剂 ·泥水調整剂などに使 用されている. 最近, リグニンス ルホン酸塩にさらにスルホン酸基 を多くつけ分子量を下け゚た安価な 界面活性を持つ溶液を廃油田に王
入し残存原油を取り出す研究がさ れており，成功すれば巨大量が使 用されるであるう。

リグリンを分解して低分子量の 化合物を得るのは，バニリンの製 造など若干利用されているが，フ テインケミカル分野で消費できる リグニン量は, 今後とすその発生 量に比し少ないるのであるう。リ グニンを利用した合成樹脂が若干 市股されているが，色・に拈いな ぞの点で問題がある.リグニンを 原料として得られる低分子化合物 より無色で汎用の合成樹脂・合成 綫維が得られてはじめて量的にも 大量消費され，「資源」と呼ばれ るようになろう。

現在, 固型分 $40 \sim 50 \%$ の濃縮 パルプ廃液が，カロリー計算より C重油価格の $20 \%$ 程度である が，石油燃料事情がタイトになっ た場合や，リグニンの大量消費用 途が開発された場合は值上がりる 予想される．含有りグニン換算で 必ずしす安い資源ではなくなる可 能珄す西り，工業化には細心の注 意が肝要である。

坂田元記（坂田技術研究所・所 長 (代表取締役), 専門=高分子 化学) 
後者はどうしても絨度もらが管理できないためと考え られる．練減率が中国糸の方が少ないのは，一つには 品種にあり, わが国のように藏采量の多い藏はセリシ ンの占める量も多くなるため7，精練により流亡する

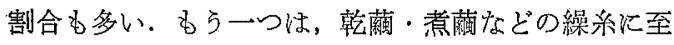
る工程管理が不適当なためと思われる。

\section{5. おおりに}

編集委員から寔が杀を吐く量は昔に比べ相当進歩し たと思うので，この点に焦点を当てて物性との関係を 書くよらにとの要望により，明治以降わが国に特ける 奛品種の改良に伴なら荋質祘よび生糸品質の推移を考 察した。

しかし,もう一つの面虽のるつ物理的岁るい化 学的特徵を応用しシルキーな䋐維をつくるため伝統的 な生物資源である虫に学ぶという見方である、事実， 繊維の歴史はいかにして綟に類似した繊維をつくりだ すかに終始していると言っても過言ではない、シャル ドンネの人造綟糸，ナイロン，キアナあるいは最近の 綟類似繊維にしても同様である。これについてもふれ たいところたが，紙面の都合上割愛する.

\section{文献}

1) 安村作郎：系統生物， 4, 26 (1979)

2) 平林 橴, 荒井三雄, 小林玉枝, 佐藤幸头: 日龺 雑, 46, 1 (1977)

3) 平林 潔, 門脇 亘, 安村作郎: 未發表

4) 埼玉県㵶維工業試験場：日本繊維新聞，53年 8 月 9 日, 10 日，14日

5) 平林 潔, 高田晋介, 荒井三雄: 製糸絹䂗究発表 会集録, 28, 127 (1978)

6) 吉武成美：宜系科学の技術，17，28（1978）

7) 中川義和, 伎竹精太郎：日虫雑, 31，341（1962）

$*$

\section{(858 頁より続く)}

的研究は多くの研究者の努力により，すでにかなりの 段階にまで達していると考えられる。したがってリグ ニンの利用はむしろ経済的にみて，実用化あるいは工 業化の価值があるかとううかということにしぼられてこ よう.リグニンという貴重なリニューアブル資源が有 效に使われることもなく，大部分然料として消費され ている現状はいずれ改善されなくてはなるまい。

\section{文献}

1) I. Falkehag: Appl. Polym. Symp., 28, 248 (1975)

2) 山田雅稳, 岡部次郎, 秦 邦男 : リグニンの化学 (中野準三螎)， 二 二広報 (1979) p. 359

.3) 中野準三, 戴 清華 : 接着, 8,818 (1964)

4) Westvaco Co.: Polychemicals Div. Technical Bull., No. 300

5) 半井勇三，小野昌孝：木材工業. 24, 84. (1969)

6) C.S. Mills : 西独特許 1145352 (1963)

7) Westvaco Co.：英国特許 933685 (1963)

8) Westvaco Co. : 英国特許 984699 (1964)

9) Merck \& Co. : 米国特許 3344023 (1967)
10) Chem. Eng. News, Jan. 26, 44 (1970)

11) G.W. Gray, P.A. Winsor : Liquid Crystals \& Plastic Crystals, Ellis Horwood (1974)

12) A. J. Herbert : Trans. Faraday Soc., 63, 555 (1967)

13）泉山兵衛，吉田博久，畠山立子：製科研報告, No. 74, 31 (1974)

14) M. Ikeda, T. Hatakeyama : Mol. Cryst. Liq. Cryst., 33, 201 (1976)

15) M. Ikeda, T. Hatakeyama : ibid., 39, 109 (1977)

16) T. Hatakeyama, M. Ikeda : ibid., 45, 275 (1978)

17) K. Iio, H. Hatakeyama : ACS/CSJ Chemical Congress, Honolulu, (Apr. 1979)

18) S. Hirose, T. Hatakeyama, H. Hatakeyama : Cellulose Chem. Technol., 12, 713 (1978)

19) H. Hatakeyama, E. Hayashi, T. Haraguchi: Polymer, 18, 759 (1977)

20) T. Hatakeyama, K. Nakamura, H. Hatakeyama: ibid., 19, 593 (1978)

21) K. Nakamura, T. Hatakeyama, H. Hatakeyama : Polymer Science, 投稿中 